\title{
PRODUKTIVITAS DAN BIAYA PERALATAN PEMANENAN HUTAN TANAMAN: STUDI KASUS DI PT MUSI HUTAN PERSADA, SUMATERA SELATAN
}

\section{(Productivity and Cost of Harvesting Equipment in Forest Plantation: Case study on PT Musi Hutan Persada, South Sumatera)}

\author{
Oleh/By :
}

\author{
Dulsalam \& Djaban Tinambunan
}

\begin{abstract}
The study on productivity and cost of harvesting equipment in PT Musi Hutan Persada, South Sumatera has been carried out to find the information aboutproductivity and cost of plantation forest harvesting equipment. The study results revealed that:

1. Felling equipment used was small-sized chainsaw of Husqvarna with an average productivity of $2.14 \mathrm{~m}^{3} /$ hour and an average cost of $\mathrm{R} p 15,334 / \mathrm{m}^{3}$.

2. Log skidding was carried out using Timber Jack G10 forwarder with an average prodwwtivity of $18.25 \mathrm{~m}^{3} /$ hour and an average cost of $\mathrm{Rp} 39,852 / \mathrm{m}^{3}$ and using Timber Jack 1010B with an average productivity of 21.25 $\mathrm{m}^{3} /$ hour and an average cost of $\mathrm{R} p 79,254 / \mathrm{m}^{3}$.

3. For log loading and unloading, log loaders of Hitachi and Volvo were used with average productivities of $70 \mathrm{~m}^{3} /$ hour for loading and $34 \mathrm{~m}^{3}$ / hour for unloading, respectively. The average loading costs for Hitachi and Volvo log loaders were consecutively $\mathrm{R} p 6,155 / \mathrm{m}^{3}$ and $\mathrm{R} p 6,200 / \mathrm{m}^{3}$, while the average aunloading costs for Hitachi and Volvo log loaders were $\mathrm{R} p 12,671 / \mathrm{m}^{3}$ and $\mathrm{R} p 12,764 / \mathrm{m}^{3}$, respectively.

4. Log haulings by single trucks had an average productivity of $5 \mathrm{~m}^{3} /$ hour and an average cost of $\mathrm{R} p 44,697 / \mathrm{m}^{3}$ and by semi trailer trucks had an average productivity of $15 \mathrm{~m}^{3} /$ hour and an average cost of $\mathrm{R} p 37,676 / \mathrm{m}^{3}$.

5. Felling tree and log hauling activities did not caused significant environmental disturbance. Log extraction using forwarders of Timber Jack G10 and Timber Jack 1010B caused low top soil displacement while tracked loading tractors of Hitachi and Volvo caused high topsoil displacement.

6. Equipment combination needs improvement and minmum log production perperiod should be determined so that log production flow can run smoothly and the workers and equipment do not have much idle time.
\end{abstract}

Keywords: Harvesting, plantation forest, appropriate equipment, productivity, cost

\begin{abstract}
ABSTRAK
Penelitian peralatan pemanenan di hutan tanaman PT Musi Hutan Persada, Sumatera Selatan telah dilakukan untuk mendapatkan informasi produktivitas dan biaya peralatan pemanenan hutan tanaman yang tepat guna dan ramah lingkungan. Hasilnya menunjukkan bahwa:
\end{abstract}


1. Alat penebangan yang digunakan adalah chainsaw (gergaji rantai) berukuran kecil merek Husqvarna dengan rata-rata produktivitas sebesar $2,14 \mathrm{~m}^{3} / \mathrm{jam}$ dan biaya sebesar $\mathrm{Rp} 15.334 / \mathrm{m}^{3}$.

2. Penyaradan dilakukan dengan menggunakan forwarder merek Timber Jack G10 dan Timber Jack $1010 B$. Rata-rata produktivitasnya berturut-turut adalah $18,25 \mathrm{~m}^{3} / \mathrm{jam}$ dan $21,25 \mathrm{~m}^{3} / \mathrm{jam}$ dengan rata-rata biaya berturut-turut sebesar $\mathrm{Rp} 39.852 / \mathrm{m}^{3}$ dan $\mathrm{Rp} 79.254 / \mathrm{m}^{3}$.

3. Pemuatan dan bongkar kayu digunakan alat merek Hitachi dan Volvo dengan rata-rata produk-tivitas masing-masing sebesar $70 \mathrm{~m}^{3} /$ jam untuk muat dan $34 \mathrm{~m}^{3} /$ jam untuk bongkar muatan. Untuk Hitachi, rata-rata biaya muat adalah $\mathrm{Rp} 6.155 / \mathrm{m}^{3}$, bongkar adalah $\mathrm{Rp} 12.671 / \mathrm{m}^{3}$, sedangkan untuk Volvo kedua besaran tersebut berturut-turut adalah $\operatorname{Rp} 6.200 / \mathrm{m}^{3}$ dan $\mathrm{Rp} 12.764 / \mathrm{m}^{3}$.

4. Pengangkutan kayu dengan truk tunggal rata-rata produktivitasnya sebesar $5 \mathrm{~m}^{3} /$ jam dengan ratarata biaya sebesar $\mathrm{Rp} 44.697 / \mathrm{m}^{3}$, sedangkan truk semi gandengan, rata-rata produktivitasnya sebesar $15 \mathrm{~m}^{3} /$ jam dengan rata-rata biaya sebesar $\mathrm{Rp} 37.676 / \mathrm{m}^{3}$.

5. Penebangan pohon dan pengangkutan kayu tidak menimbulkan gangguan lingkungan yang berarti. Penyaradan kayu dengan forwarder Timber Jack G10 dan Timber Jack 1010B menimbulkan pemadatan dan pergeseran tanah relatif kecil sedangkan pemuatan dengan alat pemuat Hitachi dan Volvo menimbulkan pergeseran tanah cukup besar.

6. Kombinasi peralatan perlu perbaikan dan produksi kayu yang minimal pada periode tertentu perlu ditentukan agar arus kayu lancar serta pekerja dan peralatan tidak banyak waktu tunggu.

Kata kunci: Pemanenan, hutan tanaman, peralatan tepat guna, produktivitas, biaya

\section{PENDAHULUAN}

\section{A. Latar Belakang}

Peralatan pemanenan di hutan tanaman masih menggunakan peralatan yang biasa digunakan di hutan alam. Pemilihan peralatan pemanenan di hutan tanaman ini perlu mendapat perhatian khusus kaitannya denagan dimensi kayu yang dipanen, tipe peralatan, teknik dan biaya pemanenan seta pengaruhnya terhadap sosial dan lingkungan. Kesalahan dalam pemilihan peralatan pemanenan dapat berdampak negatif terhadap teknik, ekonomi, sosial dan lingkungan.

Peralatan pemanenan yang diharapkan adalah peralatan yang efektif dan berdampak minimal yang pada gilirannya dapat meningkatkan pasokan kayu bundar dan bahan baku serpih. Kebutuhan kayu bundar dan bahan baku serpih cenderung meningkat. Pasokan bahan baku kayu tersebut perlu didukung oleh teknik pemanenan yang efisien dan berdampak minimal.

Salah satu cara untuk mendapatkan teknik pemanenan yang efisien dan berdampak minimal adalah dengan mengupayakan kesesuaian penggunaan peralatan pemanenan di hutan tanaman. Peralatan pemanenan tersebut sangat menentukan teknik kerja (efektivitas, produktivitas), biaya, kesjahteraan sosial dan gangguan lingkungan. Sebagai contoh, penggunaan alat pemanenan yang terlalu besar dan mempunyai kapasitas terlalu tinggi mengakibatkan biaya investasi tinggi, produktivitas rendah sebagai akibat penggunaan tenaga alat yang tidak optimal, kurang memberdayakan masyarakat dan gangguan terhadap lingkungan seperti vegetasi, tanah dan air cenderung meningkat. Penggunaan peralatan pemanenan tersebut dimaksudkan untuk memanfaatkan sumber daya hutan. 
Pemanfaatan sumberdaya hutan yang berazaskan kelestarian hasil dan kelestarian ekosistem dapat dilakukan melalui pemanenan hutan dengan menggunakan peralatan yang sesuai. Kegiatan pemanenan hutan dengan berbagai macam teknik akan mempengaruhi efisiensi, produktivitas dan biaya pemanenan. Di samping itu, kegiatan pemanenan tersebut juga mempengaruhi sosial dan lingkungan. Produktivitas pemanenan dapat dihitung dengan mengetahui waktu kerja dan hasil kerja peralatan yang digunakan. Biaya pemanenan dapat dihitung dengan cara mengetahui produktivitas pemanenan dan biaya memiliki dan biaya menjalankan alat pemanenan. Pengaruhnya terhadap lingkungan didekati dengan wawancara dengan pelaksana pemanenan. Dari indikator produktivitas, efisiensi, biaya, dan lingkungan dihimpun paket informasi yang dapat digunakan untuk menentukan pilihan peralatan pemanean yanglebih sesuai untuk hutan tanaman.

Peralatan yang digunakan untuk pemanenan di hutan tanaman sangat bervariasi. Informasi teknis dan ekonomis dari peralatan tersebut belum tersedia. Informasi tesebut dapat dijadikan bahan pertimbangan dalam pemilihan alat yang sesuai dengan kondisi hutan yang dipanen. Peralatan yang dipilih adalah secara teknis memungkinkan, secara ekonomis menguntungkan, secara sosial dapat diterima dan secara ekologis mengakibatkan gangguan lingkungan yang minimal. Penggunaan peralatan yang tepat guna dalam pemanenan hutan tanaman tersebut sangat diperlukan.

Dalam tulisan ini disajikan hasil penelitian peralatan pemanenan hutan tanaman di PT Musi Hutan Persada (MHP), Sumatera Selatan dengan cakupan kegiatan penebangan, penyaradan, pemuatan, pengangkutan dan pembongkaran, dilihat dari aspek teknis dan ekonomis. Hasil penelitian diharapkan dapat bermanfaat bagi pengambil kebijakan dan pelaksana di lapangan dalam rangka meningkatkan efisiensi pemanenan hutan tanaman.

\section{METODOLOGI PENELITIAN}

\section{A. Lokasi dan Peralatan}

Penelitian produktivitas dan biaya peralatan pemanenan hutan dilaksanakan di areal hutan tanaman PT Musi Hutan Persada (MHP), Sumatera Selatan. Obyek penelitian adalah peralatan pemanenan yang digunakan perusahaan pada tahap kegiatan penebangan, penyaradan, muat-bongkar dan pengangkutan kayu yang dibahas melalui aspek teknis, ekonomis, sosial dan lingkungan. Alat bantu yang digunakan adalah meteran, kompas, alat tulis menulis dan komputer.

\section{B. Metode}

Penelitian peralatan pemanenan hutan tanaman dilakukan dengan metode deskriptif dengan mengumpulkan data melalui kuesioner, diskusi, wawancara dan pengamatan langsung di lapangan serta menelusuri dan mengkaji hasil-hasil penelitian yang ada dan diskusi atau wawancara dengan pelaksana pemanenan.

Untuk itu prosedur yang ditempuh adalah sebagai berikut.

1) Membuat daftar kuesioner mengenai berbagai aspek peralatan pemanenan untuk diisi perusahaan terpilih.

2) Menentukan lokasi penelitian secara purposif. 
3) Melakukan diskusi dengan unsur-unsur pimpinan perusahaan mengenai kebijakan pemanenan hutan dan permasalahannya.

4) Melakukan wawancara dengan pelaksana pemanenan hutan tanaman yang meliputi: pembuatan jalan angkutan per tahun, jumlah tenaga kerja pemanenan, tarif upah tenaga kerja, jumlah peralatan pemanenan yang dimiliki, harga alat, tenaga motor, konsumsi bahan bakar, konsumsi oli, nilai bunga bank, hari kerja per tahun, jam kerja per hari, upah operator dan upah pembantu operator. Data biaya dikumpulkan pada saat kurs (nilai tukar) US $\$ 1=$ Rp 9.250 pada tahun 2003.

5) Melakukan pengamatan langsung pelaksanaan pemanenan hutan di lapangan.

6) Menganalisa data yang terkumpul dari kegiatan 1) sampai 5) di atas terutama ditinjau dari aspek teknis, ekonomis dan lingkungan.

\section{Analisa Data}

Pengolahan data dilakukan secara tabulasi. Alat analisa yang digunakan adalah rata-rata (mean). Hasil olahan adalah tersusunnya jenis peralatan yang sesuai untuk kegiatan pemanenan di hutan tanaman yang dapat digunakan sebagai bahan kebijakan. Untuk menghitung biaya peralatan pemanenan digunakan rumus-rumus dari FAO (Anonim, 1992) berikut:

1) Biaya penyusutan

Biaya penyusutan $\quad=\frac{\text { Harga alat }(\mathrm{Rp}) \times 0,9}{\text { Umur pakai alat (jam) }}$

2) Biaya bunga modal

Biaya bunga modal

$$
=\frac{\text { Harga alat }(\mathrm{Rp}) \times 0,6 \times 0,18}{1.000 \mathrm{jam}}
$$

3) Biaya pajak

Biaya pajak

$$
=\frac{\text { Harga alat }(\mathrm{Rp}) \times 0,6 \times 0,02}{1.000 \mathrm{jam}}
$$

4) Biaya asuransi

Biaya asuransi

$$
=\frac{\operatorname{Hrga} \text { alat }(\mathrm{Rp}) \times 0,6 \times 0,03}{1.000 \mathrm{jam}}
$$

5 Biaya perawatan

Biaya perawatan

$$
=\text { Biaya penyusutan }
$$

6) Biaya bahan bakar

Biaya bahan bakar = Penggunaan bahan bakar (liter/jam) $\mathrm{x}$ harga bahan bakar per

7) Biaya oli dan pelumas

$$
\text { liter (Rp/liter) }
$$

Biaya oli dan pelumas $=0,1$ biaya bahan bakar

8) Upah 
$\mathrm{U}=\mathrm{G}:(\mathrm{H} \times \mathrm{W})$

di mana: $\mathrm{U}=$ Biaya upah (Rp/jam); $\mathrm{G}=$ Gaji (Rp/bulan); $\mathrm{H}=$ hari kerja rata-rata per bulan; $\mathrm{W}=$ jam kerja per hari (jam/hari).

\section{HASIL DAN PEMBAHASAN}

\section{A. Umum}

Pemanenan hutan di MHP mampu menyerap banyak tenaga kerja seperti dirinci pada Tabel 1. Terlihat bahwa porsi terbesar alokasi tenaga adalah untuk pengangkutan $(55,8 \%)$ dan penebangan (16,5\%). Banyaknya tenaga kerja ini disebabkan dimensi kayu yang dipanen adalah relatif kecil sehingga memerlukan jumlah tenaga kerja yang cukup besar. Sebagai contoh, untuk menebang pohon dengan waktu yang sama maka penebangan pohon yang besar akan diperoleh hasil yang lebih besar.

Tabel 1. Jumlah tenaga kerja di bidang pemanenan Table1. The number of work force in harvesting

\begin{tabular}{|c|l|c|c|}
\hline No & \multicolumn{1}{|c|}{$\begin{array}{c}\text { Bidang pekerjaan } \\
\text { (Activities) }\end{array}$} & $\begin{array}{c}\text { Jumlah tenaga kerja (Number } \\
\text { of operation), orang (person) }\end{array}$ & $\begin{array}{c}\text { Persentase } \\
\text { (Percentage), \% }\end{array}$ \\
\hline 1 & $\begin{array}{l}\text { Perencanaan pemanenan } \\
\text { (Harvesting planning) }\end{array}$ & 186 & 8,6 \\
\hline 2 & $\begin{array}{l}\text { Pembuatan/pemeliharaan jalan } \\
\text { (Road construction/maintenance) }\end{array}$ & 140 & 6,5 \\
\hline 3 & Penebangan (Felling) & 357 & 5,1 \\
\hline 4 & Penyaradan kayu (Log skidding) & 111 & 6,9 \\
\hline 5 & Muat kayu (Log loading) & 150 & 55,8 \\
\hline 6 & Pengangkutan kayu (Log hauling) & 1.210 & 0,6 \\
\hline 7 & Bongkar muatan (Unloading) & 15 & 100 \\
\hline & Jumlah (Total) & 2.169 & \\
\hline
\end{tabular}

Berbagai kegiatan pemanenan di atas memberikan dampak positif pada para pekerja karena PT MHP memberlakukan tarif upah yang cukup tinggi seperti disajikan pada Tabel 2. Pada tabel tersebut terlihat bahwa tarif upah untuk muat - bongkar adalah tertinggi. Hal ini terjadi karena dimensi kayu yang dimuat dan dibongkar relatif kecil sehingg hasil kerja $\left(\mathrm{m}^{3}\right.$ kayu) per satuan waktu relatif kecil. 
Tabel 2. Tarif pekerjaan pemanenan

Table 2. Rate price of forest barvesting activities

\begin{tabular}{|c|l|c|}
\hline No & \multicolumn{1}{|c|}{ Pekerjaan (Activities) } & Tarif (Rate price) \\
\hline 1 & Penebangan (Felling) & $\operatorname{Rp~} 16.000 / \mathrm{m}^{3}$ \\
\hline 2 & Penyaradan (Skidding) & $\mathrm{Rp} 31.500 / \mathrm{m}^{3}$ \\
\hline 3 & Muat (Loading) & $\mathrm{Rp} 38.000 / \mathrm{m}^{3}$ \\
\hline 4 & Pengangkutan (Hauling) & $\mathrm{Rp} 50.000 / \mathrm{m}^{3}$ untuk jarak (For distance) $50 \mathrm{~km}$ \\
\hline 5 & Bongkar (Unloading) & $\mathrm{Rp} 38.000 / \mathrm{m}^{3}$ \\
\hline
\end{tabular}

Sampai tahun 1993, panjang jalan yang dibuat PT MHP cukup besar, yaitu mencapai 202,97 km. Periode tahun 1994 - 2002, pembuatan jalan utama berkisar antara 3,6 - 56,51 $\mathrm{km} /$ tahun seperti disajikan pada Tabel 3. Pembuatan jalan utama ini selain ditentukan dengan luas penanaman, juga ditentukan oleh kegiatan penebangan. Dalam hal ini ada jalan utama yang memang dirancang sejak penanaman. Namun, ada pula jalan utama yang dibuat pada waktu penebangan akan dilakukan, yaitu dengan cara meningkatkan jalan cabang menjadi jalan utama karena beberapa prtimbangan tertentu. Pembuatan jalan ini penting artinya bagi kegiatan penyaradan dan pengangkutan kayu. Panjang jalan yang besar mengakibatkan jarak sarad rata-rata menjadi pendek dan jarak angkut rata-rata menjadi besar (biaya penyaradan rendah, biaya pengangkutan tinggi) demikian juga sebaliknya panjang jalan yang kecil menyebabkan jarak sarad-rata-rata menjadi besar dan jarak angkut menjadi kecil (biaya penyaradan tinggi, biaya pengangkutan rendah).

Tabel 3. Panjang jalan utama yang dibuat oleh PT MHP sampai tahun 2002 Table 3. Main road constructed until 2002 by PT MHP

\begin{tabular}{|c|c|c|}
\hline No & $\begin{array}{c}\text { Tahun pembuatan } \\
\text { (Year of construction) }\end{array}$ & $\begin{array}{c}\text { Panjang jalan (Road length) } \\
(\mathrm{km})\end{array}$ \\
\hline 1 & Sampai (Unti) 1993 & 202,97 \\
\hline 2 & 1994 & 17,1 \\
\hline 3 & 1995 & 4,9 \\
\hline 4 & 1996 & 10,82 \\
\hline 5 & 1997 & 10,87 \\
\hline 6 & 1998 & 14,2 \\
\hline 7 & 1999 & 23,3 \\
\hline 8 & 2000 & 3,6 \\
\hline 9 & 2001 & 12 \\
\hline 10 & 2002 & 56,51 \\
\hline & Total & 356,27 \\
\hline
\end{tabular}


Keadaan topografi di areal hutan PT MHP adalah landai dan sedikit bergelombang dan jenis tanahnya adalah podsolik merah kuning. Kegiatan pemanenan pada areal yang demikian relatif mudah dilakukan. Aksesibilitas areal hutan cukup tinggi karena dekat dengan perkampungan penduduk. Jalan utama sebagian besar telah diperkeras dengan sistem macadam. Kegiatan pengangkutan kayu dapat berjalan lancar walaupun cuaca hujan. Sebagian besar (tidak kurang dari 80\%) tenaga kerja yang ada berasal dari masyarakat setempat. Kegiatan pemanenan hutan dapat meningkatan pendapatan masyarakat sekitarnya.

\section{B. Peralatan Penebangan}

Jenis alat penebangan yang digunakan adalah gergaji rantai (chainsaw) merek Husqvarna tipe 365 sebanyak 832 unit. Tenaga motor dari chainsaw tersebut adalah 1,5 HP. Alat bantu yang digunakan adalah baji, kikir, rantai gergaji dan bilah gergaji. Harga alat tersebut pada tahun 2002 adalah Rp 4.600.000 per unit. Waktu kerja alat penebangan per tahun adalah 2.100 jam. Umur pakai alat adalah 3 tahun. Konsumsi bahan bakar per jam adalah Rp 0,86 liter dengan harga Rp 6000/liter. Konsumsi oli per jam adalah 1,43 liter dengan harga Rp 12.000/ liter. Upah operator chainsaw per bulan adalah Rp 1.120.000 dan upah pembantu operator per bulan adalah Rp 550.000. Berdasarkan data ini dan menggunakan rumus-rumus (1) - (8) maka diperoleh biaya memiliki dan menjalankan alat penebangan dengan chainsaw Husqvarana sebesar Rp 32.860/jam dengan komponen-komponen biaya seperti terlihat pada Tabel 4.

Tabel 4. Biaya memiliki dan menjalankan chainsaw Husqvarna Table 4. The owning and operating costs of Husquarna chainsaw

\begin{tabular}{|c|l|c|}
\hline No & \multicolumn{1}{|c|}{ Komponen biaya (Cost components) } & Besaran (Values), Rp/jam (Rp/hour) \\
\hline 1. & Penyusutan (Depreciation) & 657 \\
\hline 2. & Bunga bank (Bank interest) & 497 \\
\hline 3. & Pajak (Tax) & 55 \\
\hline 4. & Asuransi (Insurance) & 83 \\
\hline 5. & Perawatan (Maintenance) & 657 \\
\hline 6. & Bahan bakar (Fue) & 17.160 \\
\hline 7. & Oli dan pelumas (Lubrication oil and grease) & 8.591 \\
\hline 8. & Upah (Wages) & 32.860 \\
\hline & Jumlah (Total) & \\
\hline
\end{tabular}


Jam kerja per hari adalah 7 jam (pukul 8.00 - 16.00 dengan istirahat 1 jam). Hasil kerja penebangan adalah $15 \mathrm{~m}^{3}$ per hari. Dengan demikian produktivitas alat adalah 2,143 $\mathrm{m}^{3}$ per jam. Biaya penebangan adalah hasil bagi biaya memiliki dan mengoperasikan alat penebangan dengan produktivitas alat yang bersangkutan. Dengan demikian biaya penebngan adalah Rp $15.334 / \mathrm{m}^{3}$. Biaya penebangan ini lebih kecil bila dibanding dengan tarif biaya penebangan setempat, yaitu Rp $16.000 / \mathrm{m}^{3}$. Tarif penebangan ini sesungguhnya kurang menguntungkan bagi pengusaha penebangan karena yang bersangkutan hanya memperoleh sedikit keuntungan, yaitu sekitar 4\%.

Di hutan tanaman yang mempunyai ukuran kayu kecil, kegiatan penebangan sebaiknya menggunakan chainsaw yang berukuran kecil seperti Husqvarna 365 karena alat tersebut mempunyai beberapa keuntungan berikut: (1) Menghemat tenaga dalam transportasi dan pengoperasiannya; (2) Memudahkan dalam membuat takik rebah dan takik balas; (3) Dapat menebang kayu dengan tunggak rendah, (4) Biaya pemilikan lebih rendah, (5) Biaya operasional relatif lebih murah, (6) Berpindah tempat lebih cepat, dan (7) Biaya pemeliharaan lebih rendah.

Produktivitas penebangan dengan chainsaw merek yang sama di PT Inhutani II, Pulau laut sebesar 3,12 $\mathrm{m}^{3} /$ jam (Dulsalam \& Tinambunan, 2001) adalah lebih besar bila dibandingkan dengan produktivitas penebangan di PT MHP. Hal ini disebabkan antara lain perbedaan keadaan lapangan dan keterampilan tenaga kerja. Di PT Inhutani II, tenaga kerja relatif lebih terampil dan topografi lapangan datar. Dalam kegiatan penebangan di PT MHP masih dijumpai terjadinya limbah penebangan, yaitu berupa tunggak yang masih tinggi dan bagian cabang yang sebenarnya masih dapat dimanfaatkan. Penebangan pohon dapat dilakukan serendah mungkin bahkan apabila memungkinkan rata dengan tanah.

Kegiatan penebangan ini banyak menyerap tenaga kerja karena satu regu tebang terdiri dari dua orang, yaitu satu operator dan satu pembantu operator dengan gaji yang cukup memadai, yaitu secara berurutan sebesar Rp 1.120.000/bulan dan Rp 550.000/bulan. Pendapatan rata-rata pekerja penebangan adalah Rp 835.000/orang/bulan. Dengan jumlah tenaga penebangan sebanyak 357 orang (Tabel 1), maka pendapatan masyarakat dari penebangan adalah Rp 298.095.000/bulan. Uang sebesar ini cukup besar manfaatnya bagi masyarakat di sekitar hutan. Secara sosial, kegiatan penebangan pohon dapat meningkatkan kesempatan kerja (mendapatkan penghasilan) bagi masyarakat di sekitar hutan.

Kegiatan penebangan dapat dikatakan tidak menimbulkan dampak terhadap lingkungan yang berarti. Pemadatan tanah dan pergeseran tanah dapat dikatakan tidak terjadi. Gangguan lingkungan yang terjadi akibat penebangan pohon ini hanyalah adanya sisa-sisa batang dan ranting yang tidak dimanfaatkan. Batang dan ranting ini apabila dihancurkan justru menjadi pupuk bagi tanaman berikutnya. Dampak lain yang terjadi adalah penurunan absorpsi karbon dan terganggunya tata air di sekitar hutan yang dipanen. Hal ini tidak dapat dihindari karena untuk mendapatkan manfaat dari hutan perlu pengorbanan tertentu. Absorpsi karbon dan tata air akan pulih kembali seiring dengan pembangunan hutan tanaman pada lokasi hutan yang dipanen.

\section{Peralatan Penyaradan}

Jenis alat penyaradan yang digunakan adalah forwader merek Timber Jack tipe G10 dan 1010B sebanyak 44 unit. Tenaga motor dari Timber Jack G10 adalah 80 HP dan Timber Jack 
$1010 B$ adalah 83 HP. Harga Timber Jack G10 pada tahun 1999 adalah Rp 2.000.000.000 sedangkan harga Timber Jack $1010 B$ pada tahun 2002 adalah Rp 5.000.000.000. Umur pakai kedua alat tersebut diasumsikan 5 tahun. Waktu kerja efektif alat tersebt ditargetkan 2.000 jam per tahun, dengan waktu kerja harian sebanyak 8 jam. Konsumsi bahan bakar solar adalah 16 liter/jam untuk tipe G10 dan 16,6 liter/jam untuk tipe 1010B dengan harga solar sebesar Rp 4.300/liter. Upah operator adalah Rp 2.500.000/bulan. Dengan menggunakan rumus (1) (8) diperoleh komponen biaya kedua alat seperti diuraikan pada Tabel 5. Dengan menjumlahkan masing-masing komponen biaya tersebut maka diperoleh biaya pemilikan dan pengoperasian alat penyaradan dengan forwader Timber Jack G10 dan forwarder Timber Jack 1010B secara berurutan adalah Rp 727.305/jam dan Rp 1.684.143/jam. Pada tabel 5 terlihat bahwa komponen biaya terbesar berasal dari bunga bank, penyusutan dan perawatan. Hal ini menunjukkan bahwa peralatan forwarder mempunyai nilai investasi yang tinggi.

Tabel 5. Biaya memiliki dan pengoperasian forwarder untuk penyaradan kayu Table 5. Owning and operating costs of forwarder for log skidding

\begin{tabular}{|c|l|c|c|}
\hline \multirow{2}{*}{ No } & \multirow{2}{*}{ Komponen biaya (Cost components) } & \multicolumn{2}{|c|}{ Besaran (Values), Rp/jam (Rp/hour) } \\
\cline { 3 - 4 } & & Timber Jack G10 & Timber Jack 1010B \\
\hline 1. & Penyusutan (Depreciation) & 180.000 & 450.000 \\
\hline 2. & Bunga bank (Bank interest) & 216.000 & 540.000 \\
\hline 3. & Pajak (Tax) & 24.000 & 60.000 \\
\hline 4. & Asuransi (Insurance) & 36.000 & 90.000 \\
\hline 5. & Perawatan (Maintenance) & 180.000 & 450.000 \\
\hline 6. & Bahan bakar (Fue) & 68.800 & 71.380 \\
\hline 7. & Oli (Lubrication oid) & 6.880 & 7.138 \\
\hline 8. & Upah (Wages) & 15.625 & 15.625 \\
\hline & Jumlah (Total) & 727.305 & 1.684 .143 \\
\hline
\end{tabular}

Jarak sarad rata-rata berkisar antara 200 - $300 \mathrm{~m}$. Hasil kerja alat tipe G10 adalah 145 $\mathrm{m}^{3} /$ hari atau $18,25 \mathrm{~m}^{3} / \mathrm{jam}$ dan tipe $1010 \mathrm{~B}$ adalah $170 \mathrm{~m}^{3} /$ hari atau $21,25 \mathrm{~m}^{3} / \mathrm{jam}$. Dengan membagi jumlah biaya memiliki dan pengoperasian (Tabel 5) dengan rata-rata produktivitas penyaradan di atas maka diperoleh biaya penyaradan dengan tipe G10 dan tipe 1010B secara berurutan sebesar Rp 39.852/ $\mathrm{m}^{3}$ dan $\operatorname{Rp} 79.254 / \mathrm{m}^{3}$. Biaya penyaradan tersebut jauh di atas tarif biaya penyaradan setempat, yaitu sebesar Rp 31.500/ $\mathrm{m}^{3}$. Untuk mengatasi masalah ini perlu dilakukan penyesuaian tarif upah dan produktivitas alat sarad.

Biaya rata-rata penyaradan kayu dengan Timber Jack tersebut lebih tinggi bila dibanding dengan biaya rata-rata penyaradan kayu dengan alat sarad lainnya. Biaya penyaradan kayu: dengan kerbau berkisar antara Rp 6.299 - Rp 29.293/m³.hm dengan rata-rata Rp 11.581/ $\mathrm{m}^{3} . \mathrm{hm}$ (Dulsalam dan Sukadaryati, 2001), dengan gajah sebesar Rp 2.021/ $\mathrm{m}^{3}$ (Dulsalam et al., 
1999), dengan kabel layang Koller 300 sebesar Rp 33. 233/ $\mathrm{m}^{3}$ (Dulsalam \& Tinambunan, 1998), dengan traktor Caterpillar D7F sebesar Rp 9.150/ $\mathrm{m}^{3}$ untuk cara terkendali dan Rp $8.000 / \mathrm{m}^{3}$ untuk cara konvensional (Suhartana \& Dulsalam, 2000), dan dengan traktor pertanian John Deer 2400 yang dilengkapi alat bantu sebesar Rp 14.055/ $\mathrm{m}^{3}$.hm (Dulsalam dan Tinambunan, 2001).

Kegiatan penyaradan kayu ini cukup banyak menyerap tenaga kerja, yaitu 111 orang (Tabel 1). Gaji operator penyaradan cukup besar, yaitu Rp 2.500.000/bulan. Pendapatan ratarata pekerja penyaradan kayu adalah $\mathrm{Rp} 2.500 .000$ /orang/bulan. Dengan jumlah tenaga penyaradan kayu sebanyak 111 orang, maka pendapatan masyarakat dari penyaradan kayu ini adalah Rp 277.500.000/bulan. Jumlah ini cukup besar manfaatnya bagi masyarakat di sekitar hutan. Secara sosial, kegiatan penyaradan kayu merupakan satu sumber pendapatan yang penting bagi masyarakat di sekitar hutan.

Kegiatan penyaradan kayu dengan forwarder Timber Jack 1010 B dan Timber Jack G10 menimbulkan gangguan lingkungan relatif kecil. Pengaruh terhadap pemadatan tanah dan pergeseran tanah dapat dikatakan relatif sedikit.

\section{Peralatan Muat}

Jenis alat muat yang digunakan adalah traktor pemuat merek Hitachi dan Volvo sebanyak 12 unit masing-masing dengan tenaga motor $180 \mathrm{HP}$. Harga traktor pemuat merek Hitachi dan Volvo pada tahun 1999 adalah Rp 780.000.000/unit dan Rp 790.000.000/unit. Waktu kerja alat per tahun adalah 2.000 jam dengan kerja harian sebanyak 8 jam. Jenis bahan bakar yang digunakan adalah solar dengan konsumsi 36 liter/jam dan harga Rp 4.300/liter. Konsumsi oli adalah 0.9 liter/jam dengan harga Rp 12.000/liter. Upah operator adalah Rp 2.000.000/ bulan. Dengan menggunakan rumus (1) - (8) diperoleh komponen-komponen biaya kedua alat seperti disajikan pada Tabel 6. Dengan menjumlahkan semua komponen biaya tersebut maka diperoleh biaya pemilikan dan pengoperasian Hitachi dan Volvo secara berurutan adalah Rp 430.820/jam dan Rp 434.000/jam (Tabel 6). Dalam tabel tersebut terlihat bahwa porsi biaya terbesar adalah untuk bahan bakar disusul bunga bank, penyusutan dan perawatan.

Jarak muat rata-rata adalah $5 \mathrm{~m}$. Hasil kerja masing-masing alat berkisar antara 500 - 600 $\mathrm{m}^{3} /$ hari atau $70 \mathrm{~m}^{3} /$ jam. Dengan membagi biaya pemilikan dan pengopersaian alat (Tabel 6) dengan produktivitas rata-rata maka biaya muat rata-rata dengan traktor pemuat Hitachi adalah $\mathrm{Rp} 6.155 / \mathrm{m}^{3}$ dan traktor pemuat Volvo adalah $\mathrm{Rp} 6.200 / \mathrm{m}^{3}$. Biaya pemuatan kayu ini jauh lebih kecil dibanding dengan tarif biaya pemuatan kayu setempat, yaitu Rp 38.000/m³. Dengan demikian, perusahaan pemuatan kayu akan mendapat keuntungan berkisar antara $513-517 \%$. Hal ini menunjukkan bahwa tarif pemuatan kayu perlu dievaluasi agar diperoleh biaya pemuatan kayu yang lebih wajar.

Produktivitas traktor pemuat lebih tinggi dibanding produktivitas pemuatan kayu secara manual. Demikian juga biaya pemuatan kayu dengan traktor pemuat lebih tinggi dibanding dengan biaya pemuatan kayu secara manual. Pemuatan kayu secara manual telah diteliti pada tahun 1999 dengan hasil sebagai berikut : produktivitas pemuatan kayu berkisar antara 2,32 $6,38 \mathrm{~m}^{3} /$ jam dengan rata-rata $3,83 \mathrm{~m}^{3} /$ jam; jarak pemuatan kayu berkisar antara 15 - $35 \mathrm{~m}$; dan biaya pemuatan berkisar antara $\mathrm{Rp} 1.990-\mathrm{Rp} 4.310 / \mathrm{m}^{3}$ dengan rata-rata $\mathrm{Rp} 3.235 / \mathrm{m}^{3}$ (Dulsalam dan Tinambunan, 2001). 
Tabel 6. Biaya memiliki dan pengoperasian traktor pemuat kayu Table 6. Owning and operating costs of log loader tractors

\begin{tabular}{|c|l|c|c|}
\hline \multirow{2}{*}{ No } & \multirow{2}{*}{ Komponen biaya (Cost components) } & \multicolumn{2}{|c|}{ Besaran (Values), Rp/jam (Rp/ hour) } \\
\cline { 3 - 4 } & & Hitachi & Volvo \\
\hline 1. & Penyusutan (Depreciation) & 70.200 & 71.100 \\
\hline 2. & Bunga bank (Bank interest) & 84.240 & 85.320 \\
\hline 3. & Pajak (Tax) & 9.360 & 9.480 \\
\hline 4. & Asuransi (Insurance) & 14.040 & 14.220 \\
\hline 5. & Perawatan (Maintenance) & 70.200 & 71.100 \\
\hline 6. & Bahan bakar (Fued) & 154.800 & 154.800 \\
\hline 7. & Oli (Lubrication oì) & 15.480 & 15.480 \\
\hline 8. & Upah (Wages) & 12.500 & 12.500 \\
\hline & Jumlah (Total) & 430.820 & 434.000 \\
\hline
\end{tabular}

Kegiatan pemuatan kayu ini cukup banyak menyerap tenaga kerja, yaitu 150 orang (Tabel 1). Pendapatan rata-rata pekerja pemuatan kayu adalah Rp 2.000.000/orang/bulan. Dengan jumlah tenaga penyaradan kayu sebanyak 150 orang, maka pendapatan masyarakat dari pemuatan kayu ini adalah Rp 300.000.000/bulan. Jumlah ini cukup besar artinya bagi perekonomian masyarakat di sekitar hutan. Secara sosial, kegiatan pemuatan kayu menjadi mata pencaharian penting bagi masyarakat di sekitar hutan. Pendapatan dari pemuatan kayu ini merupakan pendapatan terbesar kedua setelah pengangkutan kayu dibandingkan dengan pendapatan pada kegiatan lain.

Kegiatan pemuatan kayu dengan Hitachi dan Volvo menimbulkan gangguan lingkungan yang cukup berarti karena roda dari kedua alat tersebut terdiri dari rantai baja. Penggunaan alat muat Hitachi dan Volvo relatif kurang ramah lingkungan. Pengaruhnya terhadap pemadatan tanah dan pergeseran tanah cukup besar. Di samping kelemahan berupa kurang ramah lingkungan tersebut, kedua alat pemuat kurang efisien bila kegiatan muat kayu sering berpindah tempat. Kelebihan kedua alat tersebut adalah kemampuannya untuk tetap beroperasi walaupun hari hujan.

\section{E. Peralatan Pengangkutan}

Alat pengangkutan yang digunakan adalah truk yang terdiri dari beberapa merek seperti Hino, Isuzu, Mercedez, Renault, Mitsubishi, Nissan dan Volvo dengan jumlah keseluruhan sebanyak 500 unit. Tenaga motor dari truk angkutan dari berbagai jenis tersebut berkisar antara $180 \mathrm{HP}$ untuk truk tunggal (Nissan) dan $400 \mathrm{HP}$ untuk truk semi gandengan (Volvo). Harga truk tersebut pada tahun 1998 adalah Rp 500.000.000/unit untuk truk tunggal dan Rp 1.500.000.000/unit untuk truk semi gandengan. Umur pakai truk adalah 5 tahun. Waktu kerja adalah $2000 \mathrm{jam} /$ tahun dan $8 \mathrm{jam} /$ hari. Jenis bahan bakar yang digunakan adalah solar. 
Konsumsi bahan bakar adalah 10 liter/jam untuk truk tunggal dan 15 liter/jam untuk truk semi gandengan. Upah pengemudi adalah Rp 2.000.000/bulan sedangkan upah pembantu pengemudi adalah Rp 750.000/bulan. Dengan menggunakan rumus (1) - (8) diperoleh komponen biaya truk tunggal dan truk semi gandengan seperti terlihat pada Tabel 7. Dengan menjumlahkan semua komponen biaya tersebut maka diperoleh biaya pemilikan dan pengoperasian truk tunggal dan truk semi gandengan secara berurutan sebesar Rp 233.487/ jam dan Rp 565.137/jam (Tabel 7). Pada tabel ini pun terlihat bahwa porsi biaya terbesar adalah biaya bunga bank, selanjutnya disusul biaya penyusutan, perawatan dan bahan bakar.

Kapasitas angkut dari alat tersebut adalah 15 ton/rit untuk truk tunggal dan 40 ton/rit untuk truk semi gandengan. Jarak angkut rata-rata adalah $50 \mathrm{~km}$. Produktivitas alat rata-rata untuk truk tunggal adalah $5 \mathrm{~m}^{3} /$ jam dan truk semi gandengan adalah $15 \mathrm{~m}^{3} / \mathrm{jam}$. Hal ini mudah dipahami karena kapasitas dan tenaga motor truk gandengan jauh lebih besar bila dibanding dengan truk tunggal.

Tabel 7. Biaya pemilikan dan pengoperasian truk angkutan kayu Table 7. Owning and operating costs of log bauling trucks

\begin{tabular}{|c|l|c|c|}
\hline \multirow{2}{*}{ No } & Komponen biaya (Cost components) & \multicolumn{2}{|c|}{ Besaran (Values), Rp/jam (Rp/ hour) } \\
\cline { 3 - 4 } & & $\begin{array}{c}\text { Truk tunggal } \\
\text { (Single truck) }\end{array}$ & $\begin{array}{c}\text { Truk semi gandengan } \\
\text { (Semi trailer truck) }\end{array}$ \\
\hline 1. & Penyusutan (Depreciation) & 45.000 & 135.000 \\
\hline 2. & Bunga bank (Bank interest) & 54.000 & 162.000 \\
\hline 3. & Pajak (Tax) & 6.000 & 18.000 \\
\hline 4. & Asuransi (Insurance) & 9.000 & 27.000 \\
\hline 5. & Perawatan (Maintenance) & 45.000 & 135.000 \\
\hline 6. & Bahan bakar (Fue) & 43.000 & 64.500 \\
\hline 7. & Oli (Lubrication oil) & 4.300 & 6.450 \\
\hline 8. & Upah (Wages) & 17.187 & 17.187 \\
\hline & Jumlah (Total) & 223.487 & 565.137 \\
\hline
\end{tabular}

Dengan membagi biaya pemilikan dan pengoperasian alat pengangkutan (Tabel 7) dengan produktivitas rata-ratanya maka diperoleh biaya rata-rata pengangkutan dengan truk tunggal sebesar Rp 44.697/ $\mathrm{m}^{3}$ dan truk semi gandengan sebesar $37.676 / \mathrm{m}^{3}$. Rendahnya biaya rata-rata truk semi gandengan dikarenakan truk tersebut mempunyai produktivitas yang cukup tinggi. Biaya pengangkutan ini lebih kecil dibanding tarif biaya pengankutan, yaitu secara berurutan $\operatorname{Rp} 37.676 / \mathrm{m}^{3}$ dan $\mathrm{Rp} 44.697 / \mathrm{m}^{3}$ dibanding $\mathrm{Rp} 50.000 / \mathrm{m}^{3}$. Selisih antara biaya pengangkutan dan tarif biaya pengangkutan adalah keuntungan perusahaan pengangkutan. Kebaikan alat adalah dapat mengangkut kayu dengan diameter kecil sampai besar dengan aman. Kelemahannya adalah tidak dapat bongkar muat sendiri. 
Kegiatan pengangkutan kayu ini cukup banyak menyerap tenaga kerja, yaitu 1.210 orang (Tabel 1). Gaji pengemudi cukup besar, yaitu Rp 2.000.000/bulan sedangkan gaji pembantu pengemudi adalah Rp $750.000 /$ bulan. Rata-rata gaji tenaga kerja pengangkutan adalah Rp 1.375.000/bulan. Pendapatan rata-rata pekerja pengangkutan adalah Rp 1.375.000/ orang/bulan. Dengan jumlah tenaga penyaradan kayu sebanyak 1.120 orang, maka pendapatan masyarakat dari pengangkutan kayu ini adalah Rp 1.540.000.000/bulan. Jumlah ini cukup besar manfaatnya bagi perekonomian masyarakat di sekitar hutan. Secara sosial, kegiatan pengangkutan kayu memberikan kesempatan kerja bagi masyarakat di sekitar hutan. Pendapatan dari kegiatan pengangkutan kayu ini adalah yang paling besar dibanding dengan pendapatan pada kegiatan lain.

Kegiatan pengangkutan kayu baik dengan truk tunggal maupun truk semi gandengan tidak menimbulkan gangguan lingkungan yang berarti. Penggunaan alat angkut kayu dengan truk tunggal dan truk semi gandengan adalah cukup ramah lingkungan. Gangguan lingkungan yang terjadi akibat kegiatan pengengkutan kayu ini adalah timbulnya debu yang berterbangan akibat jalan hutan terlindas oleh roda alat angkutan. Gangguan ini dapat diatasi dengan cara menyiram permukaan jalan dengan air.

\section{F. Peralatan Bongkar Muatan}

Jenis alat bongkar muatan yang digunakan adalah sama dengan alat pemuatan kayu, yaitu traktor pemuat Hitachi dan Volvo. Jumlah alat bongkar kayu adalah 24 unit. Tenaga motor, harga alat, waktu kerja, konsumsi bahan bakar dan upah operator sama dengan traktor pemuat kayu Hitachi dan Volvo. Perbedaannya adalah pada produktivitas alat. Produktivitas traktor pembongkar kayu baik Hitachi maupun Volvo adalah $34 \mathrm{~m}^{3} / \mathrm{jam}$. Biaya pemilikan dan pengoperasian alat sama seperti pada biaya pemilikan dan pengoperasian alat traktor pemuat Hitachi dan traktor pemuat Volvo, yaitu berturut-turut Rp 430.820/jam dan Rp 434.000/jam seperti disajikan pada Tabel 6. Dengan membagi biaya pemilikan dan pengoperasian alat tersebut dengan produktivitas rata-rata maka biaya pembongkaran kayu dengan traktor pembongkar kayu Hitachi dan Volvo secara berurutan adalah $\mathrm{Rp} 12.671 / \mathrm{m}^{3}$ dan $12.764 / \mathrm{m}^{3}$. Biaya bongkar kayu ini jauh di bawah traif biaya bongkar kayu setempat, yaitu secara

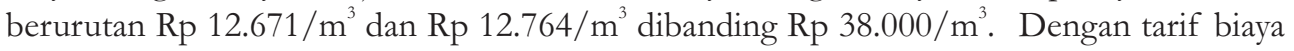
pembongkaran kayu setempat, perusahaan pembongkaran kayu dapat memperoleh keuntungan yang terlalu besar, yaitu sekitar 198 - 200\%. Tarif biaya pembongkaran kayu perlu dikurangi sesuai dengan keuntungan perusahaan yang layak. Kebaikan dan kelemahan alat sama seperti pada peralatan pemuatan.

Kegiatan pemuatan kayu ini cukup banyak menyerap tenaga kerja, yaitu 15 orang (Tabel 1). Pendapatan rata-rata pekerja pembongkaran kayu adalah Rp 2.000.000/orang/bulan. Dengan jumlah tenaga penyaradan kayu sebanyak 15 orang, maka pendapatan masyarakat dari pembongkaran kayu ini adalah Rp 30.000.000/bulan. jumlah ini cukup besar manfaatnya bagi perekonomian masyarakat di sekitar hutan. Secara sosial, kegiatan pembongkaran kayu dapat meningkatkan pendapatan masyarakat di sekitar hutan. Pendapatan dari pembongkaran kayu ini adalah yang paling kecil dibanding dengan pendapatan pada kegiatan lain. Kegiatan pembongkaran kayu dengan Hitachi dan Volvo menimbulkan gangguan lingkungan sama seperti alat pemuatan kayu dengan Hitachi dan Volvo. 
Tabel 8. Produktivitas dan biaya pemanenan

Table 8. Productivity and harvesting cost

\begin{tabular}{|c|c|c|c|c|}
\hline No & $\begin{array}{l}\text { Kegiatan } \\
\text { (Activities) }\end{array}$ & $\begin{array}{c}\text { Jenis alat } \\
\text { (Kind of equipment) }\end{array}$ & $\begin{array}{l}\text { Produktivitas } \\
\text { (Productivities) }\end{array}$ & $\begin{array}{c}\text { Biaya (Costs) } \\
\text { (Rp) }\end{array}$ \\
\hline \multirow[t]{2}{*}{1.} & \multirow[t]{2}{*}{$\begin{array}{l}\text { Penebangan } \\
\text { (Felling) }\end{array}$} & $\begin{array}{l}\text { Chainsaws: } \\
\text { - Husquarna di (in) PT } \\
\text { Musi Hutan Persada }\end{array}$ & $\begin{array}{c}2,14 \mathrm{~m}^{3} / \mathrm{jam} \\
\text { (bour) }\end{array}$ & $15.334 / \mathrm{m}^{3}$ \\
\hline & & $\begin{array}{l}\text { - Husquarna di (in) PT } \\
\text { Inhutani II 1) }\end{array}$ & $\begin{array}{c}3,112 \mathrm{~m}^{3} / \mathrm{jam} \\
\text { (bour) }\end{array}$ & $4.411 / \mathrm{m}^{3}$ \\
\hline \multirow[t]{8}{*}{2.} & \multirow[t]{8}{*}{$\begin{array}{l}\text { Penyaradan } \\
\text { (Skidding) }\end{array}$} & $\begin{array}{l}\text { Forwarders: } \\
\text { - Timber Jack G10 }\end{array}$ & $\begin{array}{c}18,25 \mathrm{~m}^{3} / \mathrm{jam} \\
\text { (bour) }\end{array}$ & $39,852 / \mathrm{m}^{3}$ \\
\hline & & - Timber Jack 1010 B & 21,25 $\mathrm{m}^{3} /$ jam (bour) & $79.254 / \mathrm{m}^{3}$ \\
\hline & & $\begin{array}{l}\text { Wheel Skidders: } \\
\text { - Winch 1) }\end{array}$ & 17,55 m³/jam (hour) & $17.277 / \mathrm{m}^{3} \cdot \mathrm{hm}$ \\
\hline & & - Grapple 1) & $10,40 \mathrm{~m}^{3} \cdot \mathrm{hm} / \mathrm{jam}$ & $28.723 / \mathrm{m}^{3} \cdot \mathrm{hm}$ \\
\hline & & Gajah (Elephant) ${ }^{1)}$ & $\begin{array}{c}3,009 \mathrm{~m}^{3} \cdot \mathrm{hm} / \mathrm{jam} \\
\text { (hour) }\end{array}$ & $2.021 / \mathrm{m}^{3}$ \\
\hline & & Kerbau $(\text { Buffalo })^{1)}$ & $\begin{array}{c}0,821 \mathrm{~m}^{3} \cdot \mathrm{hm} / \mathrm{jam} \\
\text { (hour) }\end{array}$ & $11.581 / \mathrm{m}^{3} \cdot \mathrm{hm}$ \\
\hline & & 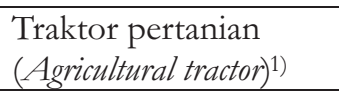 & $\begin{array}{c}\text { 7,162 } \mathrm{m}^{3} \cdot \mathrm{hm} / \mathrm{jam} \\
\text { (hour) }\end{array}$ & $14.055 / \mathrm{m}^{3} \cdot \mathrm{hm}$ \\
\hline & & $\begin{array}{l}\text { Sistem kabel layang } \\
\text { (Skyline system } \\
\text { Koller } 300)^{2)}\end{array}$ & 1,700 $\mathrm{m}^{3} /$ jam (hour) & $33.233 / \mathrm{m}^{3}$ \\
\hline \multirow[t]{2}{*}{3.} & \multirow[t]{2}{*}{$\begin{array}{l}\text { Pemuatan } \\
\text { kayu (Log } \\
\text { loading) }\end{array}$} & $\begin{array}{l}\text { Traktor pemuat kayu } \\
\text { (Log loader tractors): } \\
\text { - Hitachi }\end{array}$ & $70 \mathrm{~m}^{3} /$ jam (hour) & $6.155 / \mathrm{m}^{3}$ \\
\hline & & -Volvo & $70 \mathrm{~m}^{3} /$ jam (bour) & $6.200 / \mathrm{m}^{3}$ \\
\hline \multirow[t]{2}{*}{4.} & $\begin{array}{l}\text { Pengangkut- } \\
\text { an kayu ( } \log \\
\text { hauling) }\end{array}$ & $\begin{array}{l}\text { Truk (Trucks): } \\
\text { - Tunggal (Single) }\end{array}$ & $5 \mathrm{~m}^{3} / \mathrm{jam}$ (hour) & $44.697 / \mathrm{m}^{3}$ \\
\hline & & $\begin{array}{l}\text { - Semi gandengan } \\
\text { (Semi trailer) }\end{array}$ & $15 \mathrm{~m}^{3} /$ jam (hour) & $37.676 / \mathrm{m}^{3}$ \\
\hline \multirow[t]{2}{*}{5.} & $\begin{array}{l}\text { Bongkar } \\
\text { muatan } \\
\text { (Unloading) }\end{array}$ & $\begin{array}{l}\text { Traktor pemuat kayu } \\
\text { (Log loader tractors): } \\
\text { - Hitachi }\end{array}$ & $34 \mathrm{~m}^{3} /$ jam (hour) & $12.671 / \mathrm{m}^{3}$ \\
\hline & & - Volvo & $34 \mathrm{~m}^{3} /$ jam (hour) & $34 \mathrm{~m}^{3} / \mathrm{jam}$ (hour) \\
\hline
\end{tabular}

Keterangan $($ Remarks $): 1)=$ Dulsalam \& Tinambunan $(2001) ; 2)=$ Dulsalam \& Tinambunan (1998) 
Rangkuman produktivitas dan biaya pemanenan (peralatan penebangan, penyaradan, pemuatan, pengangkutan dan bongkar muatan) disajikan pada Tabel 8. Sesuai dengan perkembangan jaman, kegiatan pemanenan hutan tidak terlepas dari isu ramah lingkungan. Staaf dan Wiksten (1984) menyatakan bahwa lingkungan hutan itu sendiri merupakan interaksi antara geomorfologi, iklim dan geologi serta ekologi di samping matahari sebagai sumber utama energi. Keberadaan faktor dominan tersebut perlu dipertimbangkan dengan sebaik-baiknya agar kegiatan pemanenan menjamin kondisi ramah lingkungan. Ada tiga hal yang perlu diperhatikan dalam kegiatan pemanenan, yaitu (1) pilihan cara mekanisasi, (2) pilihan waktu pemanenan dan (3) pemusatan teknik operasi pemanenan pada waktu dan ruang yang tepat. Pemilihan dan jumlah penggunaan alat sangat menentukan efisiensi pemanenan kayu.

\section{KESIMPULAN DAN SARAN}

Alat penebangan yang digunakan di PT MHP adalah chainsaw berukuran kecil merek Husqvarna dengan produktivitas dan biaya yang memadai. Rata-rata produktivitasnya adalah $2,14 \mathrm{~m}^{3}$ jam dan biaya penebangan adalah $\mathrm{Rp} 15.334 / \mathrm{m}^{3}$.

Untuk penyaradan dilakukan dengan menggunakan forwarder merek Timber Jack G10 dan Timber Jack $1010 B$ dengan produktivitas yang tinggi dan dengan biaya yang tinggi pula. Ratarata produktivitas tipe G10 adalah 18,25 $\mathrm{m}^{3} /$ jam dan tipe $1010 \mathrm{~B}$ adalah 21,25 $\mathrm{m}^{3} /$ jam dengan rata-rata biayanya berturut-turut adalah $\mathrm{Rp} 39.852 / \mathrm{m}^{3}$ dan $\mathrm{Rp} 79.254 / \mathrm{m}^{3}$. Untuk pemuatan kayu digunakan traktor pemuat merek Hitachi dan Volvo dengan produktivitas tinggi dengan biaya relatif rendah. Rata-rata produktivitas kedua alat tersebut adalah $70 \mathrm{~m}^{3} /$ jam dengan rata-rata biaya berturut-turut adalah $\operatorname{Rp} 6.155 / \mathrm{m}^{3}$ dan $\mathrm{Rp} 6.200 / \mathrm{m}^{3}$. Pengangkutan kayu dilakukan dengan truk tunggal dan truk semi gandengan dengan berbagai merek yang mempunyai produktivitas dan biaya wajar. Rata-rata produktivitasnya adalah $5 \mathrm{~m}^{3} /$ jam untuk truk tunggal dan $15 \mathrm{~m}^{3} /$ jam untuk truk semi gandengan dengan biaya sebesar Rp $44.697 / \mathrm{m}^{3}$ untuk truk tunggal dan Rp $37.676 / \mathrm{m}^{3}$ untuk truk semi gandengan. Rata-rata produktivitas bongkar muatan dengan traktor pemuat merek Hitachi maupun Volvo cukup tinggi, yaitu 34 $\mathrm{m}^{3} /$ jam dengan rata-rata biaya berturut-turut sebesar $\mathrm{Rp} 12.671 / \mathrm{m}^{3}$ dan $\mathrm{Rp} 12.764 / \mathrm{m}^{3}$. Peralatan penebangan dan pengangkutan kayu tidak menimbulkan gangguan lingkungan yang berarti. Kombinasi peralatan berdasarkan produktivitas masing-masing peralatan di tiap tahap kegiatan memerlukan perbaikan agar arus produk (kayu) berjalan lancar serta waktu pekerja dan peralatan tidak banyak terbuang untuk menunggu pekerjaan.

\section{DAFTAR PUSTAKA}

Anonim. 1992. Cost control in forest harvesting and road construction. FAO Forestry Paper No. 99. FAO. Rome.

Binkley, V.W. \& H.H. Lysons. 1968. Planning Single Span Skyline. U.S. Department of Agriculture, Forest Service. Oregon.

Dulsalam, M. M. Idris \& W. Endom. 1997. Produktivitas dan biaya pengeluaran kayu dengan 
sistem kabel layang P3HH20. Buletin Penelitian Hasil Hutan 15(3): 151-161. Pusat Penelitian dan Pengembangan Hasil Hutan \& Sosial Ekonomi Kehutanan. Bogor.

Dulsalam \& D. Tinambunan. 1998. Studi kasus produktivitas dan biaya pengeluaran kayu dengan sistem kabel layang Koller 300. Buletin Penelitian Hasil Hutan 15(8):449-462. Pusat Penelitian dan Pengembangan Hasil Hutan. Bogor.

Dulsalam, M. M. Idris \& D. Tinambunan. 1999. Produktivitas dan biaya penyaradan kayu dengan gajah di suatu perusahaan hutan di Riau. Buletin Penelitian Hasil Hutan 16(5):231-253. Pusat Penelitian dan Pengembangan Teknologi Hasil Hutan. Bogor.

Dulsalam \& D. Tinambunan. 2001. Teknik pemanenan hutan tanaman. Prosiding Diskusi Teknologi Pemanfaatan Kayu Budidaya untuk Mendukung Industri Perkayuan yang Berkelanjutan, tanggal 7 Desember 2001 di Bogor: 91-113. Pusat Penelitian dan Pengembangan Teknologi Hasil Hutan. Bogor.

Dulsalam dan Sukadaryati. 2001. Produktivitas dan biaya penyaradan kayu dengan kerbau di Jambi. Buletin Penelitian Hasil Hutan 19(3):147-164. Pusat Penelitian dan Pengembangan Teknologi Hasil Hutan. Bogor.

Suhartana, S. dan Dulsalam. 2000. Pemanenan berwawasan lingkungan untuk minimasi kerusakan hutan. Buletin Penelitian Hasil Hutan 18(2):87-103. Pusat Penelitian dan Pengembangan Teknologi Hasil Hutan. Bogor.

Staaf, K.A.G. \& N. A. Wiktsen. 1984. The Harvesting Techniques. Martinus Nijjhof. Dr. W. Junk Publisher. Dordrecht/Boston/Lancaster. 